\title{
Introduction: expanding the field of research on entrepreneurship and sustainable development \\ Paula Kyrö
}

\section{INCREASING INTEREST IN RESEARCH ON ENTREPRENEURSHIP AND SUSTAINABLE DEVELOPMENT}

The combination of entrepreneurship and sustainable development has re-emerged only recently in science and slightly earlier in political debate guided by the Brundtland Commission's report (WCED, 1987), the United Nations Conference on Environment and Development in 1992, and later by the United Nations climate conference in Copenhagen. Since Pastakia's pioneering article in 1998 this discussion has intensified in just a few years in international, peer-reviewed journals as Binder and Belz's analysis in this book (Chapter 2) indicates.

However, the roots of sustainable development in science are as old as those of entrepreneurship itself (Kyrö and Suojanen, 1999; Kyrö, 2001). The very first school of thought in entrepreneurship, the French physiocrats, assumed that economic prosperity was produced by free human beings who by their own efforts, under the conditions of the self-sustaining system of nature, created something new which on its own behalf created economic progress (e.g. Barreto, 1989; Casson, 1982; Wilken, 1979). This fact, even though rarely noticed, seems also to pave the way for the current debate on sustainability and entrepreneurship, bringing along a similar movement from 'sustainable entrepreneurship' to 'making entrepreneurship sustainable', as Hjorth and Steyaert (2009) argue is achieved in social entrepreneurship.

As is typical of a nascent field of research, its understanding, approaches and forms are diverse, and seem to be open to different interpretations in different contexts, as, for example, Johannisson et al. argue in Chapter 5. This contextual bond is also apparent in other chapters of this book. Often entrepreneurship seems to be taken as a transitional tool to tackle the crucial problems calling for change in society and economy. For example, North American and European discourses can be identified. A characteristic of the North American discussion is to take social entrepreneurship as 
a starting point and then to move forward to, or combine it with, ecological sustainability. In Europe and especially in the Nordic countries social entrepreneurship has its own specific place and ecological discussion is often combined with environmental or institutional economics. Thus the landscape of entrepreneurship and sustainability is coloured by diverse approaches and perspectives.

This diversity was the stimulus to compile this Handbook in order to explore and gather these diverse perspectives and thus paint a picture of the past and present understanding of entrepreneurship and sustainable development, to inspire researchers, teachers and policy makers to intentionally develop their own understanding and help them to add their contribution to this landscape.

\section{DIVERSITY OF APPROACHES AND CONCEPTS}

Even though the approaches for the alliance between entrepreneurship and sustainable development are diverse, when it comes to sustainable development they seem to be explicitly or implicitly inspired by the United Nations report on Our Common Future. It defines sustainable development as 'meeting the needs of the present without compromising the ability of future generations to meet their needs' (WCED, 1987). How to do that and what is the role of entrepreneurship in this process seems to be an underlying question for most of the chapters in this book. Many of them draw their arguments from the transformative capacity or power of entrepreneurship towards more sustainable development in our society, its institutions and practices. Only time will tell if this debate is about to bring 'entrepreneurship for sustainable development' as an umbrella concept for the alliance between entrepreneurship and sustainable development, as some authors suggest (Montiel and Ceranic, Chapter 8; Poldner and Branzei, Chapter 14). Currently we can still identify the relationships between entrepreneurship and sustainable development that are characterized by all 'and', 'within' and 'for' definitions.

Whatever the answer may be, the 'how' and 'role' questions have already broadened our conceptualizing debate today and introduced new concepts alongside the better-known terms 'ecopreneurship', 'environmental entrepreneurship' and 'sustainable entrepreneurship'. For example, 'societal entrepreneurship' is ably introduced in Chapter 5 by Johannisson et al., and 'policy entrepreneurship' is conceptually presented in Chapter 6 by Ganesh Keremane, Jennifer McKay and Zhifang Wu.

Within these questions and diverse concepts the most vivid definitional discussion of this book concerns the 'chicken and egg' question: is the 
pursuit of economic, social and environmental goals simultaneous or does one or more of them supercede the others. The dynamics between these three is also a fundamental choice in formulating research questions and designs in this book, as is well elaborated in Chapter 15 'Market-driven capabilities and sustainability of alliances by agricultural small and medium-sized enterprises' (Sciarelli and Tani). Struggling between often competing objectives of economic, social and ecological value creation, as for example Binder and Belz (Chapter 2) as well as Cannatelli et al. (Chapter 7) argue, leads us to an increased conceptual complexity that is well demonstrated in this book.

Methodological choices of the chapters as typical of the nascent field of research focus on qualitative methods endeavouring to provide a more profound understanding of and new insights on the topic and the dynamics between its diverse dimensions. However, they also offer some previously lacking empirical evidence on different aspects of entrepreneurship and sustainable development. Thus they also methodologically advance research on the field by elevating it from prescriptive to descriptive research (Hall et al., 2010).

\section{STRUCTURE AND CHAPTERS OF THE BOOK}

The book is divided into four parts. Part I contains the chapters that shed light on the historical roots and current conceptual approaches to the alliance between entrepreneurship and sustainable development. Thus it outlines the landscape of past and present research on the topic.

Part II underlines the transformative capacity and power of entrepreneurship for a sustainable society. Like Binder's and Belz's (Chapter 2) aspect of transition, it offers examples of different levels of the impact of entrepreneurship for a sustainable society. Reaching over the previous criticism of the prescriptive nature of current research (Hall et al., 2010), it also offers descriptive empirical evidence of the dynamics between entrepreneurship and sustainable development in and for society. The four chapters in this part draw their ideas from Malawian, Haitian, East-Timorian, Australian and Swedish contexts.

Part III gathers together those chapters that investigate entrepreneurs' drivers, motivators and intentions vis-à-vis sustainable development. Following Patzelt and Shepherd's (2011) pioneering work, the chapters in this part add to our knowledge of the individual-level factors of the opportunity process in the context of sustainable entrepreneurship. As in Part II, based on empirical evidence the chapters also present the current phase of the research on this topic. 
Finally, the six chapters in Part IV broaden our view of how sustainability is integrated and embedded in industry- and economy-level research.

\section{PART I HISTORICAL ROOTS AND CURRENT CONCEPTUAL APPROACHES TO THE ALLIANCE BETWEEN ENTREPRENEURSHIP AND SUSTAINABLE DEVELOPMENT}

This part starts with a socio-historical study 'To grow or not to grow? Entrepreneurship and sustainable development'. Drawing on environmental economics, Chapter 1 elaborates the less discussed recommendation of the Brundtland Commission's report (WCED, 1987) and the United Nations Conference on Environment and Development (UNCED), namely their recommendation to replace the ideology of continuous economic growth with the principles of sustainable development. Following scientific discussions over time it reveals some misunderstandings in the research on the history of entrepreneurship and builds up an alternative discussion of growth. It also isolates entrepreneurship and ecological economics from other paradigms in environmental economics. As an outcome of this journey the chapter offers us a chronological and theoretical description of how, through entrepreneurship, economy and sustainable development can join hands and produce a new approach to the discussion between economy and welfare. The study also reveals how the social sciences not only say how things are, but also produce the reality around us. Thus the chapter both gives us a historical understanding of the current discussion between entrepreneurship and sustainable development and also demonstrates the transitional nature and transformative power of entrepreneurship in economics.

Chapter 2 written by Julia Katharina Binder and Frank-Martin Belz from the German entrepreneurship research community of TUM School of Management is a conceptual study that delineates what sustainable entrepreneurship is. Its systematic literature review ends up with a definition that reflects five aspects of sustainable entrepreneurship: the sources of opportunities; a process-focused perspective; the individual sustainable entrepreneur; economic, ecological and social value creation; and the transition to a sustainable society. Consequently this chapter offers all researchers an excellent opportunity to reflect their own conceptual understanding of sustainable entrepreneurship.

Together these two chapters provide an overall landscape for understanding the past and present conceptual discussions of entrepreneurship 
for and also within sustainable development. Thus the reader is well equipped to explore the other chapters of the book and benefit from these fundamental discussions in their own work.

\section{PART II THE TRANSFORMATIVE APPROACH TO ENTREPRENEURSHIP FOR A SUSTAINABLE SOCIETY}

The four chapters in this part underline the transformative capacity and power of entrepreneurship for sustainable development in society. The part is organized according to two different contexts: on the one hand that of developing societies, and on the other hand that of mature democracies with well-established public sectors, assuming that these differences are reflected in how entrepreneurship for sustainable development emerges in these societies.

In Chapter 3, 'Socially sustainable entrepreneurship: a case of entrepreneurial practice in social change and stability', the Danish scholars Toke Bjerregaard and Jakob Lauring argue that social sustainability is an inherent aspect of the entrepreneurial process. Their ethnographic study on the implementation of liberal democracy in Malawi examines the strategies through which entrepreneurs navigate the multiple institutional logics of the spheres in which they operate and, in turn, contributes to both sustaining and changing societal structures. Thus the chapter, drawing on institutional theory, gives us insights into the complexity of a transitional change in society.

The next chapter continues this discussion on democratization processes in fragile nations. Steffen Farny, a German researcher from the Finnish Aalto University, and his colleague Santiago Delgado Calderon from Cornell University, USA, follow socio-historical findings (Kyrö, Chapter 1) on the power of the dominating scientific debates to promote sustainable development. The authors suggest that entrepreneurship could be the missing link for democratization and development in fragile nations. Drawing on the negative experiences of foreign aid, they focus on the change-making side of entrepreneurship and sustainable development, arguing that we lack an understanding of how organizational strategies affect the quality of democratic institutions. Relying on Huang's (2008) findings from China, they suggest that neither international aid nor government intervention, but rather local entrepreneurs, can be the main agents driving societal renewal and accelerating economic liberalization. The findings of their ethnographic content analysis of the institutionbuilding process in Haiti and East Timor, however, indicate that entrepre- 
neurial activity is now supporting a parallel system rather than aiding the development process of a sovereign nation. Thus their study on the one hand verifies the findings of Bjerregaard and Lauring, and on the other reveals the basic assumptions that prevent transformations.

Chapter 5, 'Organizing societal entrepreneurship: a cross-sector challenge', written by a large Swedish research consortium - Bengt Johannisson, Anders W. Johansson, Elisabeth Sundin, Karin Berglund, Erik Rosell, Birgitta Schwartz, Rebecca Stenberg and Malin Tillmar takes us into the welfare state context. The authors argue that in a welfare economy social enterprising typically appears as a mobilizing and innovative effort that crosses the boundaries between the market, the public sector and the non-profit and voluntary sector. The chapter introduces the notion of 'societal' entrepreneurship and presents an analysis of its features through seven narrations. These narrations are drawn from the consortium's extensive work on the topic in Sweden. The authors propose that societal entrepreneurship has five dualistic features that can be positioned using an institutional framework: (1) the interplay between economic and social values over time; (2) the tension between agency and structure; (3) entrepreneurship as individual initiative or collective mobilization; (4) balancing economies of scale and the beauty of smallness; (5) social venturing as exploiting opportunity or organizing opposition. Thus the chapter offers us a more profound understanding of the notion of societal entrepreneurship in the context of the welfare state.

The last chapter of this part transports us to another continent with the Australian scholars Ganesh Keremane, Jennifer McKay and Zhifang Wu. Chapter 6, 'Public servants as sustainability policy entrepreneurs in Australia: the issues and outcomes', introduces the concept of the sustainability policy entrepreneur rarely dealt with in journals specializing in entrepreneurship. In this case the focus is on water planners who are appointed officials and have adopted the sustainable development philosophy contained in all Australian water and other natural resource legislation since 1992 (NWC, 2004; McKay, 2005). These authors deal with entrepreneurship and sustainable development by selecting a topic that is important in their Australian context and investigating the policy entrepreneur's role in the adoption of changes to water allocations. The findings from their survey of water planners and interviews with other key actors indicate how policy transition is an evolving process, where sustainability policy entrepreneurs have an important role in shaping policy outcomes. Thus the chapter expands our conceptual understanding of the diverse forms of sustainable entrepreneurs and their role in policy processes.

Together these four chapters on the transformative approach introduce 
the diverse contexts and forms of sustainable entrepreneurs and entrepreneurship. They verify the argument of the Swedish consortium (Johannisson et al., Chapter 5) about the importance of context in understanding the transformative nature of entrepreneurship and sustainable development.

\section{PART III MOTIVATIONAL AND INTENTIONAL APPROACH TO ENTREPRENEURSHIP AND SUSTAINABLE DEVELOPMENT}

This part focuses on an individual entrepreneur in pursuit of sustainable development. All the chapters centre on what makes an individual entrepreneur engage in an entreprenial venture for sustainable development.

In Chapter 7 the Italian researchers Benedetto Cannatelli, Laura Maria Ferri, Matteo Pedrini and Mario Molteni investigate the psychological dimensions leading individuals to the identification of first-person entrepreneurial opportunities for sustainable development. Based on the literature on opportunity recognition they build a set of propositions, and then using grounded theory in the Kenyan context suggest that entrepreneurial knowledge and knowledge of the natural and communal environment play a major role in feasibility assessment, but altruism and the perception of goodwill towards the natural and communal environment constitute the main drivers of the desirability assessment of the opportunity. Their findings indicate that both knowledge and motivation are moderated by the emotional and social involvement of the entrepreneur with the beneficiaries of the initiative. Thus, as called for by Binder and Belz (Chapter 2), this chapter replicates some of the previous findings of Patzelt and Shepherd (2011), increasing their validity, yet it also makes its own specific contribution to the opportunity process research for sustainable development.

Chapter 8, 'Cooking up solutions for climate change: the role of sustainable entrepreneurs', written by Ivan Montiel and Tara Ceranic from the USA, continues the opportunity discussion. The authors suggest that sustainable entrepreneurship is an umbrella under which social and environmental concerns are both addressed equally in the enterprise. The study adopts Zahra et al.'s (2009) typology of three different social entrepreneurs, and adapts it to the sustainability context by investigating how three types of search processes exist among entrepreneurs interested in climate change mitigation. The findings from their multiple case study indicate similarities between entrepreneurs aiming to create social wealth (social entrepreneurs) and those who aim to minimize their footprint (sus- 
tainable entrepreneurs). In addition, the findings reveal how enterprises tend to tackle both social and environmental projects at the same time, rather than choosing between the two. Thus the results confirm their claim and bring Zahra et al.'s model into a new context.

The Algerian-Tunisian-French research team of Azzedine Tounés, Fafani Gribaa and Karim Messeghem build 'An exploratory model of the environmental intention of SME directors in Tunisia' in Chapter 9. By combining the theory of planned behaviour of Ajzen (1991) and the entrepreneurial theory of Kuhndt et al. (2004) they explore what kind of relations exist between company directors' environmental intentions and their antecedents in the textile industry in Tunisia. The results of their qualitative survey of 20 company directors give ideas for further research by suggesting the type of connections between intention and the factors likely to explain it. As the authors argue, being able to understand the determining factors of the managers' environmental intentions advances both theoretical and policy development in the field.

In Chapter 10 the Spanish research group of Samuel Gómez-Haro, Vera Ferrón-Vílchez, José Manuel de la Torre-Ruiz and Javier DelgadoCeballos from the University of Granada investigate what motivates hotel managers to become ecopreneurs. For them, ecopreneurs are entrepreneurs who look for profitable businesses with strong underlying green values. On the basis of Post and Altman's (1994) three categories of motivations, the authors suggest that the motivational factors of ecopreneurs, in addition to compliance-, market- and value-driven motivations, also include the personal environmental values of entrepreneurs (that is, intrinsic motivation). Their case study on the Spanish hostel industry supported this suggestion, but also revealed that the willingness to meet the ecological demands of customers was the main motivator for adopting an advanced environmental management strategy.

In Chapter 11, Rita Klapper and Paul Upham from the UK investigate 'The impact of micro-firm everyday practices on sustainable development in local communities'. This chapter is part of a bigger research project on how entrepreneurial micro business owners contribute to sustainable development by pursuing their own values. The authors argue that comparatively little is known about the role of micro businesses in sustainable development, particularly the ways in which they combine entrepreneurship with environmental protection and social benefit. The authors provide a model that connects micro-firm entrepreneurship and value creation to the economic, social and environmental aspects of sustainable development. The case study findings indicate that these firms are driven by the owner-manager's values, which find their expression in monetary and non-monetary value creation. 


\section{PART IV INDUSTRY-AND ECONOMY-ORIENTED APPROACHES TO ENTREPRENEURSHIP AND SUSTAINABLE DEVELOPMENT}

Part IV presents six industry- and economy-oriented chapters. The first of these, Chapter 12 by the Italian scholars Roberto Parente and Rosangela Feola, 'The renewable energy industry: competitive landscapes and entrepreneurial roles', argues that in sustainable industry a positive role exists for both 'Emerging Davids' (new entrants) and well-established 'Greening Goliaths' (incumbent firms). They investigate the entry strategies of key players in the emerging renewable energy industry in Italy and how their strategic choices are influenced by the competitive landscapes in which they take place. The chapter contributes to our understanding of the entrepreneurial roles in new industry development by proposing a model for analysing, from a static and a dynamic perspective, the competitive structure of the renewable energy sector.

From the renewable energy industry in Italy we move to Swedish clean technology innovations. In Chapter 13 the researchers Sofia Avdeitchikova from The Ratio Institute and Lars Coenen from the Lund University Centre for Innovation, Research and Competence in the Learning Economy (CIRCLE) research centre in Sweden focus on the interplay of agency and structure in 'Commercializing clean technology innovations: the emergence of new business in an agency-structure perspective'. They argue that research in the entrepreneurship literature has often failed to explain why some new technologies reach markets while others do not, and also why some technological solutions ultimately become industry standards while others quickly disappear from the market. The authors provide an alternative approach to analyse the entrepreneurial process of commercializing 'cleantech' that underlines the duality of structure and agency. The contribution of the chapter lies in making explicit the agency-structure discussion in order to add to our understanding of cleantech as an emergent technological field and the role of entrepreneurs and/or entrepreneurship in shaping this field.

Next, still following the David and Goliath theme, we move from technology to the world of design in Chapter 14 by the Swiss researcher Kim Poldner and the Canadian Oana Branzei entitled 'David versus Goliath: how eco-entrepreneurs transform global ecosystems'. Their study elaborates the micro-practices by which individual human beings can transform global ecosystems. Reporting on a five-year multi-method study of the global ethical fashion industry, the authors expand Tillman Lyle's (1999) framework as they express it 'by marrying it' to the literature on entrepreneuring (Rindova et al., 2009; Steyaert, 2007). As an outcome they 
propose a theoretical framework that explains how eco-entrepreneurs use material, discursive and connective practices - that is, the artefacts, language and community - to progressively improve the ecosystem they work in.

From design we move in the two following chapters closer to the earth, that is, to the agricultural industry. The Italian scholars Mauro Sciarelli and Mario Tani's Chapter 15 concerns 'Market-driven capabilities and sustainability of alliances by agricultural small and medium-sized enterprises'. The authors argue for the importance of their topic as agricultural entrepreneurs are under pressure to use a more intense, and often less sustainable, way of growing crops. Drawing on Passet's (1996) hierarchical bioeconomy model of sustainability, they compile a framework that builds upon market-driven capabilities and analyse the opportunities and risks related to different agricultural farms' alliances. By adopting the multiple case study method they then investigate what kinds of capabilities are used in successful farmers' alliances. Their results indicate that agricultural alliances do not always succeed in driving agribusinesses toward more sustainable strategies, and they are able to help local development only if the alliance does not involve some other bigger players further down their value chain. According to the authors these results indicate that the bioeconomy model can provide researchers with the needed guidance for assessing if a given model of alliance can really help in sustainable development processes.

In Chapter 16 the Belgian multidisciplinary group of Marcus Dejardin, Jean Nizet and Denise Van Dam investigate organic farmers' entrepreneurial functions. Drawing on the classical work of Schumpeter, Knight and Kirzner they focus on three entrepreneurial functions: innovation, risk-taking and contribution to efficiency. Through the narrated experiences of three organic farmers the authors show how these entrepreneurial functions may be transposed in the practice of organic farming. Thus they bring the industry of organic agriculture into the entrepreneurship discussion by claiming that this evolving industry represents a renewal of agricultural activities, and organic farming can be seen as a way to achieve sustainability in agriculture and, more broadly, in the agro-food industry.

In the last chapter of the book, Chapter 17, Tõnu Roolaht from Estonia introduces us to 'The entrepreneurial contribution of foreign-owned companies to the sustainable development of a small developing host economy'. He investigates how foreign-owned companies support the sustainable development of a small host economy through their entrepreneurial initiatives. The results indicate that foreign-owned companies do indeed foster sustainable entrepreneurship in the small open economy, but the environmental, economic and social dimensions of sustainability 
are not always perfectly aligned, at least in the short term. The implications of this research for theory are that the sustainable entrepreneurship concept should be viewed as more heterogeneous and multidimensional than several studies assume.

\section{EXPECTATIONS FOR THE FUTURE}

As the chapters of this book demonstrate, the alliance between entrepreneurship and sustainable development is an evolving field with diverse meanings depending on the lenses through which we view it. Even though the authors of this book seek to clarify the differences between diverse definitions, and so provide suggestions for drawing boundaries between different concepts and approaches, the complexity and ambiguity remain as a challenge for future research. On the one hand the chapters are good examples of the conceptual diversity, and on the other their voice is similar when it comes to calling for a better understanding of this diversity.

It has become clear that the interest in and concern about entrepreneurship and sustainability issues are globally shared by scientific communities. However it is equally obvious that to flourish and grow this research needs global collaboration, since concepts and forms of entrepreneurship are context-bound and can be developed and adopted only by sharing them among different contexts. There also seems to be a consensus independent of the level of analysis that a transformative aspect is implicitly or explicitly embedded in all concepts and approaches in the field of entrepreneurship and sustainable development. This indicates that perhaps Hjorth's ideas of the movement from 'sustainable entrepreneurship' to 'making entrepreneurship sustainable' is characteristic of the current phase of research (Hjorth and Steyaert, 2009). Perhaps this book also indicates that Hall's (2012) claim that research is rather prescriptive than descriptive has been advanced somewhat by the findings in this handbook. In this nascent, evolving field of research this Handbook represents an initial effort to elaborate the view of the global research community, and most certainly new handbooks are needed in future to follow and share the findings of this expanding field of research.

\section{REFERENCES}

Ajzen, I. (1991), 'The theory of planned behaviour', Organizational Behaviour and Human Decision Process, 50, 179-211. 
Barreto, H. (1989), The Entrepreneur in Microeconomic Theory: Disappearence and Explanation, London, UK and New York, USA: Routledge.

Casson, M. (1982), The Entrepreneur: An Economic Theory, Oxford: Martin Robinson.

Hall, J., G. Daneke and M. Lenox (2010), 'Sustainable development and entrepreneurship: past contributions and future directions', Journal of Business Venturing, 25(5), 439-48.

Hjorth, D. and C. Steyaert (eds) (2009), The Politics and Aesthetics of Entrepreneurship, Cheltenham, UK and Northampton, MA, USA: Edward Elgar.

Huang, Y. (2008), Capitalism with Chinese Characteristics: Entrepreneurship and the State, Cambridge: Cambridge University Press.

Kuhndt, M., V. Türk and M. Herrndorf (2004), 'Stakeholder engagement: an opportunity for SMEs?', UNEP industry and environment, pp. 40-43, October-December.

Kyrö, P. (2001), 'To grow or not to grow? Entrepreneurship and sustainable development', International Journal of Sustainable Development and World Ecology, 8, 15-28.

Kyrö, P. and U. Suojanen (1999), 'The relationship between sustainable development and entrepreneurship in the postmodern transition', International Journal of Entrepreneurship, $3,30-52$.

McKay, J. (2005), 'Water institutional reforms in Australia', Water Policy, 7(1), 35-52.

National Water Commission (NWC) (2004), 'National Water Initiative', www.nwc.gov.au (accessed 28 July 2011).

Passet, R. (1996), L'Economique et le vivant, 2nd edn, Paris: Payot.

Pastakia, A. (1998), 'Grassroot ecopreneurs: change agents for a sustainable society', Journal of Organizational Management, 11(2), 157-73.

Patzelt, H. and D.A. Shepherd (2011), 'Recognizing opportunities for sustainable development', Entrepreneurship Theory and Practice, 35(4), 631-52.

Post, J. and B. Altman (1994), 'Managing the environmental change process: barriers and opportunities', Journal of Organizational Change Management, 7(4), 64-81.

Rindova, V., D. Barry and D. Ketchen (2009), 'Entrepreneuring as emancipation', Academy of Management Review, 34(3), 477-91.

Steyaert, C. (2007), 'Of course that is not the whole (toy) story: entrepreneurship and the cat's cradle', Journal of Business Venturing, 22(5), 733-51.

Tillman Lyle, J. (1999), Design for Human Eco-Systems: Landscape, Land Use and Natural Resources, New York: Island Press.

Wilken, P.H. (1979), Entrepreneurship: A Comparative and Historical Study, Norwood, NJ: Ablex.

World Commission on Environment and Development (WCED) (1987), Brundtland Report: Our Common Future, Oxford: Oxford University Press.

Zahra, S.A., E. Gedajlovic, D. Neubaum and J.M. Shulman (2009), 'A typology of social entrepreneurs: motives, search processes and ethical challenges', Journal of Business Venturing, 24, 518-32. 
Paula Kyrö - 9781849808248 Downloaded from PubFactory at 04/26/2023 07:08:01AM via free access 